Finance earlier.

The root of the problem is that although STA controls one of the largest science and technology budgets in the government, it has very little political power. The special promotion funds were introduced by the late Ichiro Nakagawa, a powerful member of the ruling Liberal Democratic Party (LDP), when he headed STA in the early 1980s. But Nakagawa was roundly defeated by Yasuhiro Nakasone in the run-up for prime minister in 1982. And Nakagawa subsequently committed suicide in a hotel in Hokkaido in 1983.

With Nakagawa's death, the special promotion fund lost its strongest political backer, and the Ministry of Finance, which was annoyed by the way in which Nakagawa and his supporters had bulldozed the new fund through the Diet, has been putting up bureaucratic barriers to the fund ever since.

David Swinbanks

\section{JAPANESE BUDGET}

\section{End of year splurge \\ Tokyo}

THE rush to spend money at the end of the Japanese fiscal year is by no means confined to the special promotion funds of the Science and Technology Agency. Any motorist in Tokyo will testify to the horrendous traffic jams in the city in late March caused by local governments digging up the roads (whether they need to or not) in order to use up the fiscal year's

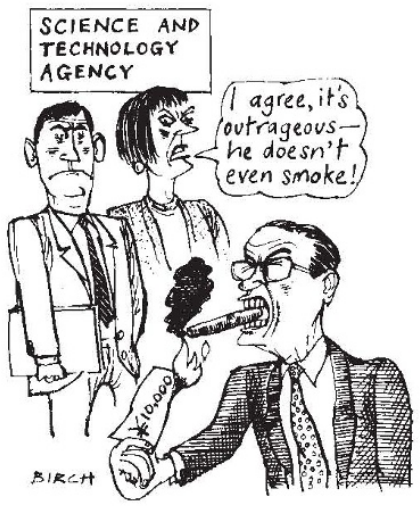

construction budget to make sure their budgets are not cut the following year.

And all booksellers know that February-March is the best time for their salesmen to visit universities and research institutes, because scientists are looking for ways to spend the rest of their book budget before the fiscal year ends. Booksellers set aside a 'dedu stoku', or 'dead stock', consisting of unsold books, which they sell off at a discount to researchers wanting to get rid of unused funds.

Many researchers say in private that they consider the annual splurge a disgraceful waste of taxpayers' money, but they cannot fight the system.

David Swinbanks

\title{
Let nature take its course
}

\section{London}

THE Gulf states should resist the urge to clean oil from their smothered beaches, say a group of British ecologists at the Natural Environment Research Council (NERC) who were asked by the UK Department of the Environment to assess the environmental effects of the huge slick now drifting down the Saudi Arabian coast. The region's wildlife may take years to recover, but the additional disturbance caused by removing beached oil means this tactic would do more harm than good, says NERC's Brian Bayne.

Bayne's conclusion is based on studies of previous oil spills, notably the Amoco Cadiz wreck off the coast of Northern France in 1978, where saltmarshes that had been left alone recovered more quickly than those from which oil had been removed. Although his team rejects the idea of physical removal of the oil, Bayne believes it will be possible to accelerate the natural bacterial breakdown of oil by spraying fertilizing nutrients onto oiled beaches (see Nature 349, 447; 7 February 1991). The 'latent' oil-feeding bacterial population is limited by a lack of nitrates in Gulf coastal waters, Bayne says.

The NERC report also recommends that the most ecologically vulnerable stretches of coastline should be protected using oil-diverting booms. Bayne is particularly concerned about the fate of the shallow water seagrass beds around the island state of Bahrain.

Most oil-damaged habitats are expected to recover in time, but Bayne says that smothered coral reefs may not be so lucky. The high salt content and relatively low temperature of the Gulf means that the corals are living near the limits of their physical tolerance. Damaged reefs may 'flip' to a completely different ecosystem, says Bayne, with corals unable to return.

The report urges that monitoring of the breakdown of spilled oil and the ecological damage and recovery should begin as soon as possible. This is difficult, given that much of the affected area is a war zone, but Bayne hopes surveys will begin within the next two months. The ecological impact of oil pollution in tropical waters has been studied extensively only once before, after an 8 million litre spill into the Caribbean in 1986, near the Panama Canal. That happened on the doorstep of the Smithsonian Tropical Research Institute's Galeta Marine Laboratory, so marine ecologists were able to make a thorough 'before and after' comparison. They found that reef corals and the seagrass fauna were badly hit. A similar study should be possible in the Gulf, using data collected before the war by Saudi and Kuwaiti scientists, although some Kuwaiti data may now have been destroyed.

Peter Aldhous

\section{Water project dropped}

\section{Johannesburg}

THF Botswana government and Greenpeace International have issued a joint statement announcing that the southern Okavango Integrated Water Development Project has been abandoned. The plan to dredge the southern stretch of the Boro River, one of the main channels flowing through the Okavango Delta in northwest Botswana, met with opposition from Greenpeace, which had threatened an international boycott of beef and diamonds, the country's two main exports. But the government finally suspended work on the project when more than a thousand representatives of the delta's inhabitants converged on the town of Maun on 11 January to hold a 'kgotla' (crisis meeting) to protest against the scheme to Archie Mogwe, Minister of Mineral and Water Affairs.

The project was intended to provide water for both domestic and agricultural use in the Maun area, which lies at the foot of the delta, and for the De Beers diamond mine at Orapa, which accounts for a considerable portion of the country's foreign exchange earnings.
Some ecologists, were concerned that the project would inevitably lead to a dropping of the water level, which would have adversely affected the delta's ecosystems, which derive their rare characteristics from it being a broad but shallow body of water. The delta is fed by the Kavango River, which rises in the Angola high lands ad flows inland, creating a seasonal floodplain. Its inhabitants are largely dependent on the natural resources of the delta for their livelihood, for which they fish, and more recently, act as tourist guides.

De Beers appeared ambivalent about the implications of the scheme's abandonment for the future of Orapa, as the company set up its own water supply for the mine three years ago by drilling boreholes. Alternative arrangements will have to be made for improving Maun's domestic water supply, and plans for large-scale irrigation will have to be abandoned. But the interesting aspect of the Botswana government's about-face is that it appears to have been prompted by local opposition.

Michael Cherry 